SMART Journal, Volume 6, No. 2, August 2020, Page 127 -135

ISSN Cetak : :2356-2048

ISSN Online : :2356-203X

\title{
DEVELOPING RUBIK'S CUBE VOCABULARY FOR ELEMENTARY SCHOOL
}

\author{
Widya Saraswati ${ }^{1)}$, Rahmatika Kayyis, M.Pd ${ }^{2)}$ Kurniati, M.Pd ${ }^{3)}$ \\ 1) 2) ${ }^{3}$ English Education Department of FKIP UMPRI \\ Email Correspondence: widyasaras28@gmail.com
}

\begin{abstract}
The Research and Development aimed to find out the target needs and the learning needs and develop appropriate English learning materials especially for using media in learning process for Grade 5 students at Elementary School of Muhammadiyah Gisting. The purpose of this study is to increase and develop the students' vocabulary in daily activity. The product of this study is using two different types of rubiks, $2 \times 2$ and $3 \times 3$ rubik. In each rubik has a worksheet. Based on the material evaluation and implementation, the students can increase their vocabulary using these rubik and the rubik is so useful for learning process.
\end{abstract}

Keywords: Vocabulary, Rubik, Worksheet

\section{INTRODUCTION}

Materials take an important part in teaching and learning process. To conduct English learning material means aimed at support the students' competence in English study program, so it should be based on the learners' needs, and they should represent the material in a good way. The materials are not using specific English vocabulary, whereas English vocabulary and the materials in every unit which is needed by the students in their future occupation will be different. Vocabulary is one of the core components of language proficiency and determines how well learners speak, listen, read, and write (Richards \& Renandya, 2002).

The problems happened of the students at Elementary of Muhammadiyah Gisting. the problems were most of students did not understand what the native said and they new vocabulary, the students were lack control over the speed at which the speakers or teacher speak and also some of student have lack motivation to learn English especially about vocabulary in the class. English

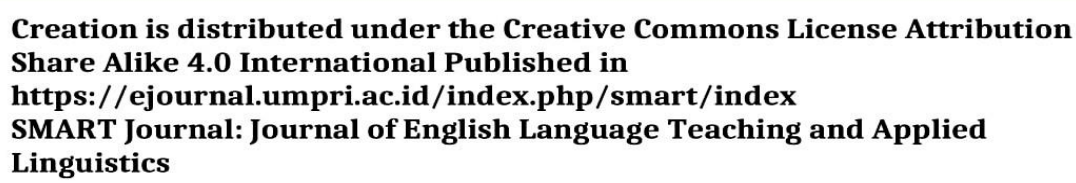


teachers usually teach their students by using available textbooks, but sometimes the teacher using media that available around the school, for example the teacher was using clock when the material explains about time. However, the English learning materials which were really suitable with the needs of the students were not always available. In that school, there were a little bit media to learn English. The teacher rarely used conventional method and just gave the materials based on the textbooks that available in that school.

The media is important to increase their ability in English learning process especially to help them to get many vocabularies because if they have many vocabularies, so they can learn English easily. Because it was for the students of elementary school, so the media must be fun, colorful and interesting. So, the researcher decided to overcome those problems and develop the English materials by using Rubik's Cube Vocabulary. In this research, the researcher developed English materials and focused in vocabulary even like a verb or sentence of students. Vocabulary is needed for comprehension of the language and it also increases fluency in the language (Nunan, 2003). According to Cameron (2001:73) Vocabulary is about learning words, children are not only expected to know the word but also they have to know what the meaning of that word.

There are some researches related to this study. Firstly, the research done by Diyah Nur Fadilah, Rahmat Rais and Diana Endah Handayani (2012) entitled "Developing TACTIC (Thematic Box ) Number Head Together at First Grade of Elementary School in Semarang”. TACTIC is a combination of Exploding / Explosion Box, pop-ups, pictures and rubik as a vehicle for play. The development of TACTIC (Thematic Box ) comes from media exploding / explosion or explosive boxes developed for thematic subjects, then there are pop-ups, rubik with images and symbols related to my theme sub themes of my body. Rubik is used as a vehicle for games and evaluation cards so that learning is more fun for first grade students in elementary school. 
Secondly, the study conducted by Syarif Amin Al Habib, Utami Widi Astuti, and Nilam Astari (2018) entitled "REDUCTION (Rubik Education) as an innovation learning media excretion system in humans, (Biology Education, Muhammadiyah University of Surakarta)". From research findings, this reduction aims to make biology learning about the excretory system in humans work and achieve well. In this reduction there is a red rubik consisting of images of the liver, kidneys, lungs and skin. So this product can help the teacher and also the student to learn about excretion system in humans easily and REDUCTION is effective to be applied as the learning media and can solve several problems in teaching and learning process in the class.

Thirdly, the study conducted by Hilmi Khoirudin Nurul Fata (2017) entitled "Developing of RUBOSAN Media ( Rubik Organ Respiratory) to Improve Student Learning Results of Organ Materials in Animal and Human at the Fifth Grade of Elementary School 1 of Bogosari”. From research findings, the specifications of the product for the development of learning devices are helped by the Rubosan learning media (Rubik Respiratory Organ) as follows: 1. Products developed in the form of RUBOSAN learning media when class $V$ students open rubik media can find pictures on each side of the rubik that have been arranged images of animal and human respiratory organs, so that students are easier to understand with the media. 2. Pictures of animal and human respiratory organs are presented in an interesting and detailed manner so that students become enthusiastic and understand more easily about the material of respiratory organs in animals and humans. Collins (2017) describes Rubik's Cube is a puzzle consisting of a cube of six colors, each face of which is made up of nine squares, eight of which are individually rotatable

The researcher do need analysis to found information about what are the students need in their language skills. Some experts defined about need analysis according to Hutchinson and Waters ( 1987:54) define needs as the ability to comprehend and to produce the linguistic features into two categories : target needs are what knowledge and abilities the learner will require in order 
to be able to perform appropriately in the target situation. The analysis of the target needs is divided into three points which are necessities, lacks and wants.

\section{RESEARCH METHODS}

In this research, the researcher used Research and Development (R\&D). This research was classified into Research and Development (R\&D) that adapted the framework of developing English learning materials by Gall, Gall and Borg (2003). The researcher tried to develop the products related with the aims of the research itself. Research and Development is a process used to develop and validate educational products. The objective of this research is to develop appropriate model of English learning materials for Elementary School Program. Therefore, this research was classified a Research and Development (R\&D), because it aims to develop a finished the product. It can be used appropriately in an educational program (Borg, 2002:772).

The organization of the research procedure adopted from Dick and Carey in Borg and Gall (2003:571). The steps were (1) Need Analysis, (2) Planning design, (3) Designing the materials, (4) First Validation Product, (5) Expert Judgment, (6) Revising 1, (7) Try out the product, (8) Revising 2, (9) Implementation the product. In this study, the data was collected through observation and questionnaires. Firstly, by observe the guide books. Secondly, the questionnaire consists of kind : (1) The need analysis questionnaire was used to gather the information about the learners and learning needs. The learners were asked to answer several questions related to their characteristics and needs in learning English by choosing one of several options that provided. The English teacher and the Headmaster were interviewed to support the data from the questionnaire. Secondly, the expert of judgment questionnaire. Opinion and suggestions from the experts are proposed through the expert judgments questionnaire to find the appropriateness of the designed materials analysis by arranging its goodness as proposed by Suharto (2006: 52-53). Thirdly, test contain of some assignment that related to the material in the 
Developing...

product. The purpose was to know the score of the students when used the product.

\section{FINDINGS AND DISCUSSIONS}

\section{a. The Results of the Needs Analysis}

A need analysis was conducted to assess the students' target and learning needs. The questionnaire was distributed to the students in 12 November 2019. Target needs cover a number of important distinctions which included necessities, lacks, and want ( Hutchinson and Waters 1987 : 54)The results are described below:

Table 1 Students' Necessary

\begin{tabular}{|c|c|}
\hline Items & The students necessities in learning English \\
\hline A & $\begin{array}{l}\text { The reason of the students need media in their learning process because it can } \\
\text { help them to memorize and improve their vocabulary }\end{array}$ \\
\hline B & Students need media to learn English that can bring everywhere \\
\hline $\mathrm{C}$ & Students need other source in English learning, not only from book \\
\hline $\mathrm{D}$ & $\begin{array}{l}\text { Students need learning vocabulary list and the meaning in English learning } \\
\text { process }\end{array}$ \\
\hline $\mathrm{E}$ & $\begin{array}{l}\text { Students need to show picture or other media to help them in English learning } \\
\text { process }\end{array}$ \\
\hline $\mathrm{N}$ & 23 \\
\hline $\mathrm{F}$ & 1792 \\
\hline Percentage & $78 \%$ \\
\hline
\end{tabular}

The table shows that the most of students consider that they need media for learning English to help them to improve and memorize new vocabulary in English learning process, need source to learn not only form book, and they also need the media that show the picture and can bring everywhere. The need analysis from 23 of students grade five in Elementary School of Muhammadiyah Gisting they almost give the score 3-5 in the analysis questionnaire. Here the researcher take the frequency in general score, after the researcher analysis the students necessities the researcher sum the score into 
general frequency. So here the researcher found the score in necessities learning English vocabulary materials for students in Elementary School of Muhammadiyah Gisting is (78\%).

Table 2 The Result of Students' Lacks

\begin{tabular}{cl} 
Items & The students lack in learning English \\
\hline $\mathrm{A}$ & Students difficulties to memorize new vocabulary \\
\hline $\mathrm{B}$ & $\begin{array}{l}\text { Students difficult to understand what their teacher say if the teacher using } \\
\text { English language }\end{array}$ \\
\hline $\mathrm{C}$ & Difficult to express some words using English \\
\hline $\mathrm{D}$ & Difficult to learn English \\
\hline $\mathrm{E}$ & Sometimes students feel bored when they learn English \\
\hline $\mathrm{N}$ & 23 \\
\hline $\mathrm{F}$ & 1244 \\
\hline Percentage & $54 \%$ \\
\hline
\end{tabular}

The table shows about the students lack in learning and teaching process. In need analysis questioner the lack from learning English they give score 1-5. The difficulties that students in learning English materials is the students' lacks in memorizing, difficult to express words or sentences, difficult to learn English because they do not understand the meaning of words or vocabulary. From 23 respondent the researcher get general frequency is get score 1244 it means that they less in English vocabulary materials is ( 54\%)

\section{Table 3 The Result of Students Wants}

\begin{tabular}{cl} 
Items & The students want in learning English \\
\hline A & Students like the learning process more fun \\
\hline B & Students are more enjoy for learning if there is media \\
\hline C & Students like learning English vocabulary with pictures and colorful \\
\hline D & Students like media that can be use to learn while play \\
\hline E & Students like learning vocabulary using their own skills \\
\hline N & 23 \\
\hline F & 1948 \\
\hline Percentage & $85 \%$ \\
\hline
\end{tabular}

The table shows the analysis questioner the students want about learning English get score frequency 1948, it means that they want learning English more fun, they also want a media when they learning English, and when they 
learning English vocabulary they can see about the pictures and also colorful, they also want in the media it is making they have fun in learning process. From their want in analysis questionnaire they almost give score from 3 until 5. From the result above, it can be conclude that the students' wants in learning English are being able to master in vocabulary is $(85 \%)$.

\section{b. Syllabus}

The syllabus is used as the guideline to develop the learning materials. The design of the syllabus based on the results of the needs analysis questionnaire. The developed syllabus consist of the identify of the syllabus, core competence and basic competence, the number and names of the each units. The analysis syllabus to help researcher make the product for the students of Elementary School. Syllabus in second semester in Elementary School is about vocabulary of daily activity

\section{c. Drafting Material}

The draft of materials consists of two rubik. The first one is $2 \times 2$ rubik's and the second one is $3 \times 3$ rubik's. There are worksheets to supported the implementation of the Rubiks

\section{d. The expert judgment}

After the writer draft of the materials was developed, the materials were then evaluated by expert judgment. The evaluation was conducted by providing a questionnaire to the expert. The questionnaire consists of four aspect, there are: appropriateness of content, presentation, language and graphic and using Likert Scale to collect the data

\section{e. Revisions of the materials}

Overall the media of Rubik's Cube Vocabulary for Elementary School are adequate, there are some suggestion from two experts judgment about the materials 


\section{CONCLUSION}

The result of implementation of Rubik's Cube Vocabulary and also the worksheet are the student understood about the materials that has given from the researcher and the students have good score in each part of the worksheet that consist of four activity, and they very enjoyed with the Rubik's Cube Vocabulary and the worksheet. So the Rubik's Cube Vocabulary and the worksheet that has used in this research can help the students in English learning process.

The suggestion is related to the input of the materials. Based on the results of need analysis, the students of Elementary Student Grade 5 want to use more media in learning process, that the media should be make the student more interest to learn. It is suggested to provide the media more colorful and insert some pictures for the need of material's presentation. The pictures may help the students to acquire the materials well and motivate students in the learning process.

\section{REFERENCES}

Al Habib, S.A., Astuti, U.W., Astari, N. (2018). Rubik Education as an Innovation Learning Media Excretion System in Human. Biology Education. University of Muhammadiyah Surakarta.

Cameron, L. (2001). Teaching Language to Young Learners. Cambridge: Cambridge University Press.

Collins Dictionary.(2017) Retrieved from https://www.collinsdictionary.com/dictionary/english/rubik-cube at November, 23,2018 at 13:53.

Fadilah, D.N., Rais, R., Handayani, D.E. (2012). Developing Thematic Box Number Head Together at First Grade of Elementary School in Semarang. (Journal). Semarang : University of PGRI Semarang.

Fata, H.K. (2017). Developing of Rubik Organ Respiratory to Improve Student Learning Results of Organ Materials in Animal and Human at the Fifth Grade of Elementary School 1 of Bogosari. (Thesis). University of PGRI Semarang. 
Developing...

Gall, Meredith. D., Gall, Joyce. P., and Borg, Walter. R. (2003). Educational Research: An Introduction ( $7^{\text {th }}$ ed). Boston : Allyn and Bacon.

Hutchinson, T and Waters, A. (1987). English for Specific Purposes. Victoria: Cambridge University Press.

Khalifah. (2018). Designing English Vocabulary Materials for Teknik Sepeda Motor(TSM) Program. Thesis. English Education Department. Lampung: UMPRI.

Nunan, David. (2003). Practical English Language Teaching. New York: McGraw Hill Company.

Richard, Jack. C and Renandya, Willy. A. (2002). Methodology in Language Teaching. Cambridge : Cambridge University Press.

Suharto, G (2006). Pengukuran Hasil Belajar Bahasa Inggris. Yogyakarta: P3B, UNY. 